\author{
V.Yu. Kirillov, V.P. Aleka, A.A. Ivashchenko, A.N. Rakhimzhanov, \\ N.S. Kelgenbayev, D.U. Auezov, G.S. Aitekov, T.N. Stikhareva* \\ A.N. Bukeikhan Kazakh Research Institute of Forestry and Agroforestry, Shchuchinsk, Kazakhstan \\ *Corresponding author: kazniiles@mail.ru
}

\title{
Current state and future development potential of the oak forests in the floodplain of the Ural River (West Kazakhstan)
}

\begin{abstract}
The article provides information on the current state of the oak forests of the Ural River floodplain (West Kazakhstan) based on the analysis of forest inventory materials (as of 01.01.1992 and 01.01.2016) and field surveys. The study of the dynamics of the oak forests (Quercus robur L.) is timely and relevant due to the important ecological role of the oak forests as the most resilient among floodplain forests, and the need to preserve their biological diversity near the south-eastern limit of the natural distribution range. Over a 24-year period, the area of the oak forests decreased by 98.7 hectares $(4 \%)$. During the study there has been a decrease in the stand density and site productivity, as well as the predominance of mature stands reproduced through re-sprouting. Pure oak forests or oak forest with an insignificant admixture of Ulmus laevis Pall., Populus alba L. and Acer negundo L. are the most common oak forest types. Natural regeneration of $Q$. robur is unsatisfactory or absent altogether. The total projective cover of the grass layer is up to $90 \%$, however, its floristic diversity is low. Authors of the article present estimates of the carbon balance of the oak forests under various management scenarios, obtained by using the EX-ACT tool. We stress the need to develop measures aimed at preserving these unique forests, including promotion of the natural regeneration of Q. robur and the creation of sustainable forest plantations. To reduce the impact of anthropogenic factors on oak forests (felling, grazing, recreation, etc.), we propose to create a specially protected area in the region.
\end{abstract}

Keywords: Quercus robur, floodplain forest, site quality class, age composition, stand density, natural regeneration, EX-ACT, anthropogenic impact.

\section{Introduction}

Protection of forests in general and preservation of their biological diversity in particular is a globally paramount task, which is especially relevant for poor forest countries such as the Republic of Kazakhstan. According to the Committee of Forestry and Wildlife of the Ministry of Ecology, Geology and Natural Resources of the Republic of Kazakhstan [1], as of 01.01.2021 the total area of the state forest fund was 30047.7 thousands ha, of which 13316.9 thousand hectares were covered by forest; thus, the forest cover was ca $4.9 \%$. The most important forest stands are those with the predominance of rare, economically valuable species. The oak forests growing in the floodplain of the Ural River are among such forest stands.

Within its natural distribution range, an oak (Quercus robur L.) is an economically valuable forest tree; it is one of the dominant species of deciduous forests in many European countries. In Russia, it grows from St. Petersburg in the north to the steppe zone in the south, and from the eastern country border to the western slopes of the Ural Mountains. In Kazakhstan, the oak grows only in the floodplain forests of the Ural River within the West Kazakhstan region, where it reaches the south-eastern limit of its distribution range [2]. Being a rare type, Q. robur is listed in the Red Data Book of Kazakhstan [3]. It has been suggested [4] that oak forests, together with the characteristic elements of the herbaceous layer, penetrated into the territory of Kazakhstan from the Cis-Urals only in historical time.

Oak ecosystems have been extensively studied across the world, from the 19th century onwards. Let us focus on the studies carried out on the territory of Kazakhstan and in the regions of Russia bordering on the West Kazakhstan region.

In the available literature, we found descriptions of the general silvicultural characteristics and growing conditions of the oak forests of West Kazakhstan [5], results of detailed floristic and geo-botanical studies of vegetation in the floodplain of the Ural River, including the oak forests [6-10], and characteristic features of the growth and productivity of forest stands in the region [11]. A typological forest classification was developed, which is still used in forest inventory; according to this classification, the oak stands are described as "oak forests of medium and high levels of the central floodplain" [2]. By origin, they are represented by those reproduced by seed and re-sprouting. 
The floodplain forests of the Ural River have a European character [6] that is in their structure and species composition, they are similar to forests in the central regions of the European part of Russian Federation. The ongoing processes of the oak forests degradation and other vegetation of the floodplain are due to changes in the hydrological regime, as well as a high level of anthropogenic impact (fire, grazing, etc.) $[12,13]$. Over a fifty-year period, the southern boundary of the distribution of $Q$. robur in the floodplain of the Ural River shifted from $49^{\circ} 40^{\prime} \mathrm{N}$ to $51^{\circ} 15^{\prime} \mathrm{N}$ [14]. Nevertheless, in the absence of significant anthropogenic load, oak can be a stable and viable species even in the steppe climate [6].

The ongoing anthropogenic transformation of natural ecosystems makes the problem of decreasing biodiversity of the oak forests more acute [15-17]. Of particular concern is the fact that the reduction in the oak forests area and their condition deterioration under the influence of both climatic and anthropogenic factors is noticeable even in the regions with optimal growing conditions, i. e. in the centre of the distribution range, including European countries such as Slovenia and Serbia, as well as the Central regions of Russia [18-21]. Negative factors have a particularly strong influence on the oak forest near the limits of their natural distribution range.

Sustainable forest management plays a significant role in mitigating climate change impacts either by reducing $\mathrm{CO}_{2}$ emissions or by capturing and storing atmospheric $\mathrm{CO}_{2}$. The former can be achieved by reducing deforestation and forest degradation rate, introducing improved agricultural practices (limited land cultivation, integrated use of nutrients and water resources); and the latter, by applying methods of conservation agriculture and improving forest management, by afforestation, reforestation and agroforestry, and by improving grassland management and restoring degraded lands.

To conduct a preliminary assessment of the impact of agriculture and forestry projects on greenhouse gas emissions and carbon sequestration, Food and Agriculture Organization (FAO) developed an Ex-Ante Carbon-balance Tool (EX-ACT). This method allows to estimate the overall impact of a project on the carbon balance, compared with the conservative approach scenario (Fig. 1). Carbon balance is defined as the net balance of all greenhouse gases, expressed in carbon dioxide equivalent that was emitted or isolated as a result of the project. EX-ACT is a land-based accounting system that measures carbon stocks, stock changes per unit of land, and $\mathrm{CH}_{4}$ and $\mathrm{N}_{2} \mathrm{O}$ emissions, expressed in tonnes of $\mathrm{CO}_{2}$ per hectare per year [22-25]. Of particular interest is the use of this method to assess the carbon balance of the oak forests in Western Kazakhstan as the most valuable declining forest ecosystems.

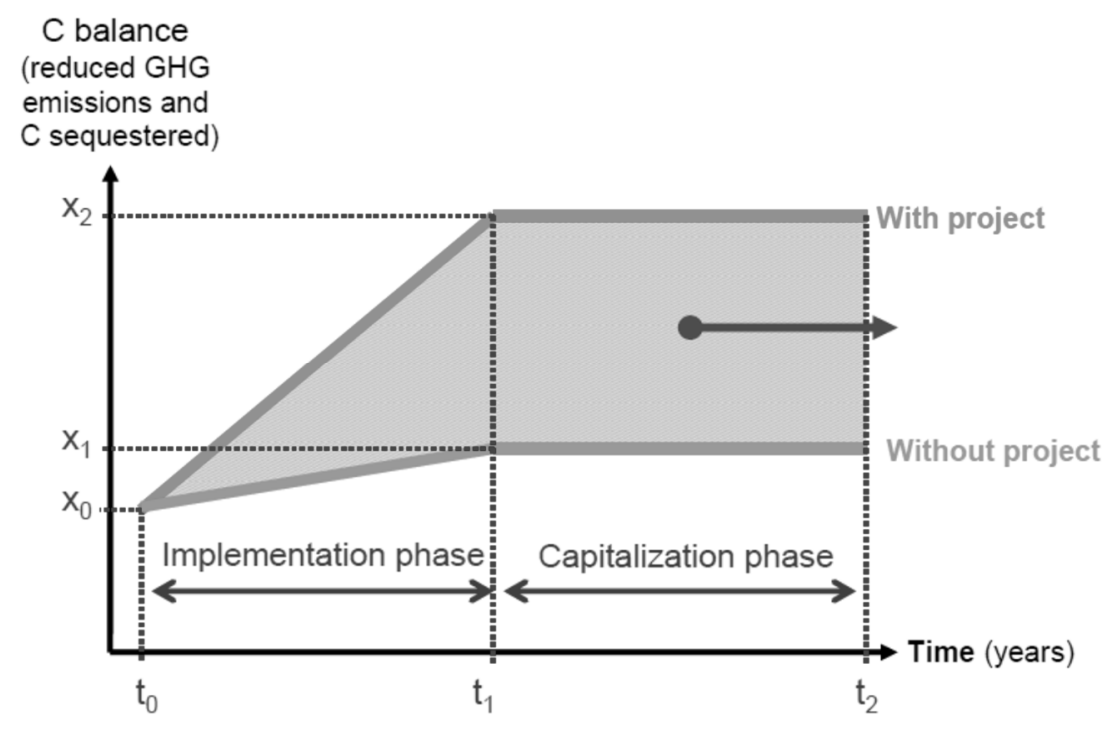

Figure 1. Logic diagram of the EX-ACT method

Taking into account a small forest area, ecological role of forests, as well as the need to increase both, the Strategic Plan of the Ministry of Ecology, Geology and Natural Resources of the Republic of Kazakhstan for 2020-2024 developed the strategic direction "Ensuring the protection, reproduction and rational use of flora and fauna, water resources and specially protected natural areas" [26]. At the same time, special attention should be paid to rare species, especially if they are the main forest-forming species. One of such species is $Q$. robur which forms the most durable floodplain forests in Western Kazakhstan. Therefore, the study 
of the oak forest dynamics is timely and relevant. In view of the increasing negative impact of climatic and anthropogenic factors, technologies and methods of sustainable forest management developed with the help of predictive modelling should become a priority. Analysis of the available literature revealed that despite a long period of research, the majority of studies have focused on the geo-botanical and floristic features of plant communities in the Ural River floodplain, and only a few, on the silvicultural characteristics and dynamics of the oak forests; the carbon balance of the oak forest has never been estimated.

The specific research objectives of the present study are: i) to assess the current state of the oak forests in the floodplain of the Ural River (West Kazakhstan) using forest inventory materials and our own experimental data; ii) to estimate the carbon balance of the oak forests using various management scenarios; iii) to develop recommendations for the protection and regeneration of these unique natural objects.

\section{Experimental}

\section{Characteristics of the study area and analysis of the forest inventory materials}

The studies were carried out in West Kazakhstan. This region is located in the subzone of light chestnut desert-steppe (semi-desert) soils. The strongly continental climate of the region is characterized by wide temperature fluctuations between day and night, and between winter and summer, as well as by a rapid seasonal change, especially from winter to summer. The climate is also characterized by little rainfall and thin snow cover, also by low air humidity. Annual precipitation is $239-273 \mathrm{~mm}$. The isotherms of January and July are $-11^{\circ} \mathrm{C}$ and $+24{ }^{\circ} \mathrm{C}$, respectively. The main part of the territory is occupied by the basin of the Ural River, which divides the region into two approximately equal parts. Within the study region, the length of the river is $781 \mathrm{~km}$, and within the country, $1084 \mathrm{~km} \mathrm{[27].} \mathrm{To} \mathrm{study} \mathrm{the} \mathrm{dynamics} \mathrm{of} \mathrm{the} \mathrm{main} \mathrm{forest} \mathrm{inventory}$ parameters (the forested area by forest owner, age class, basal area, and site productivity class), the materials of the Republican State Treasury Enterprise (RSTE) "Kazakh Forest Management Enterprise" were analyzed. Specifically, we focused on the characteristics of the oak forests in the West Kazakhstan region as of 01.01 .1992 [28] and of 01.01.2016 [29].

\section{Survey of the sample plots}

During the growing season of 2021, we carried out detailed studies of the oak forests using sample plots with a size of $50 \mathrm{~m} \times 50 \mathrm{~m}$. On the sample plots, the following parameters were measured: tree diameter at breast height (using a caliper), tree height (using a Haglof altimeter), tree age (by taking cores), and basal area. The natural regeneration of tree species and undergrowth were studied using sample plots with a size of $1 \mathrm{~m} \times 1 \mathrm{~m}$ established within the main sample plot according to the standard methods [30,31]. On each sample plot, we measured the total projective cover of all plants and all species [32]. We also identified all plant species found on the plots. The taxonomic affiliation of plants was determined in compliance with the Flora of Kazakhstan (1956-1966) [33]. The nomenclature of species followed the International Plant Names Index (IPNI) [34]. Species were assigned to the category of rare according to the Red Data Book of Kazakhstan [3]. In total, five sample plots were established in the Burlinskiy and Yanvartsevskiy communal state institutions (CSI) for the protection of forests and wildlife of the Department of Natural Resources and Environmental Management of West Kazakhstan region. The coordinates of the sample plots were established by GPS.

\section{Development of the carbon balance scenarios}

The EX-ACT V9.0 tool [35-36] was applied to assess the carbon balance of the oak forests under various management scenarios. The tool used the following region-specific coefficients: climate, moisture regime, dominant regional soil type, and vegetation type. Two scenarios were taken as examples [37].

Scenario 1. Potential carbon benefits were calculated based on the following assumptions:

- Silvicultural activities involve tree planting in areas that have previously not been forested, and include land preparation, planting of oak and other species, and sustainable management of the created forest areas. The total area to be planted is 30 ha (6 ha of mixed oak stands to be planted over five years) [28]. It should be emphasized that in 1992-2016, in the West Kazakhstan region oak plantations were created and registered as forested lands in a satisfactory condition in an area of only 2.9 ha, which, in our opinion, is inadequate.

- Forestry activities aimed at restoration of degraded forested areas without planting trees imply an improvement of the state of the oak forests and their management. Restoration of degraded forests will be achieved through the promotion of natural regeneration, better protection and conservation of the oak forests, enforcement of relevant laws, and by use of modern management practices. The "moderate" degradation level is to be changed to the "low" over 20 years. According to the available forest management data 
[28], the area of the oak forests of 3-5 site productivity classes, including reproduced through re-sprouting oak forests, was 2318.5 ha. This area was taken as the one with the "moderate" level of degradation (Table 1).

Scenario 2. Calculation of carbon benefits was made for 2318.5 ha of degraded oak forests, where the initial level of degradation was "moderate" and changed due to the 15 -years sustainable management to the "very low" level of degradation (Table 1).

Ta a le 1

Methodology for calculating the carbon balance according to the proposed Scenarios

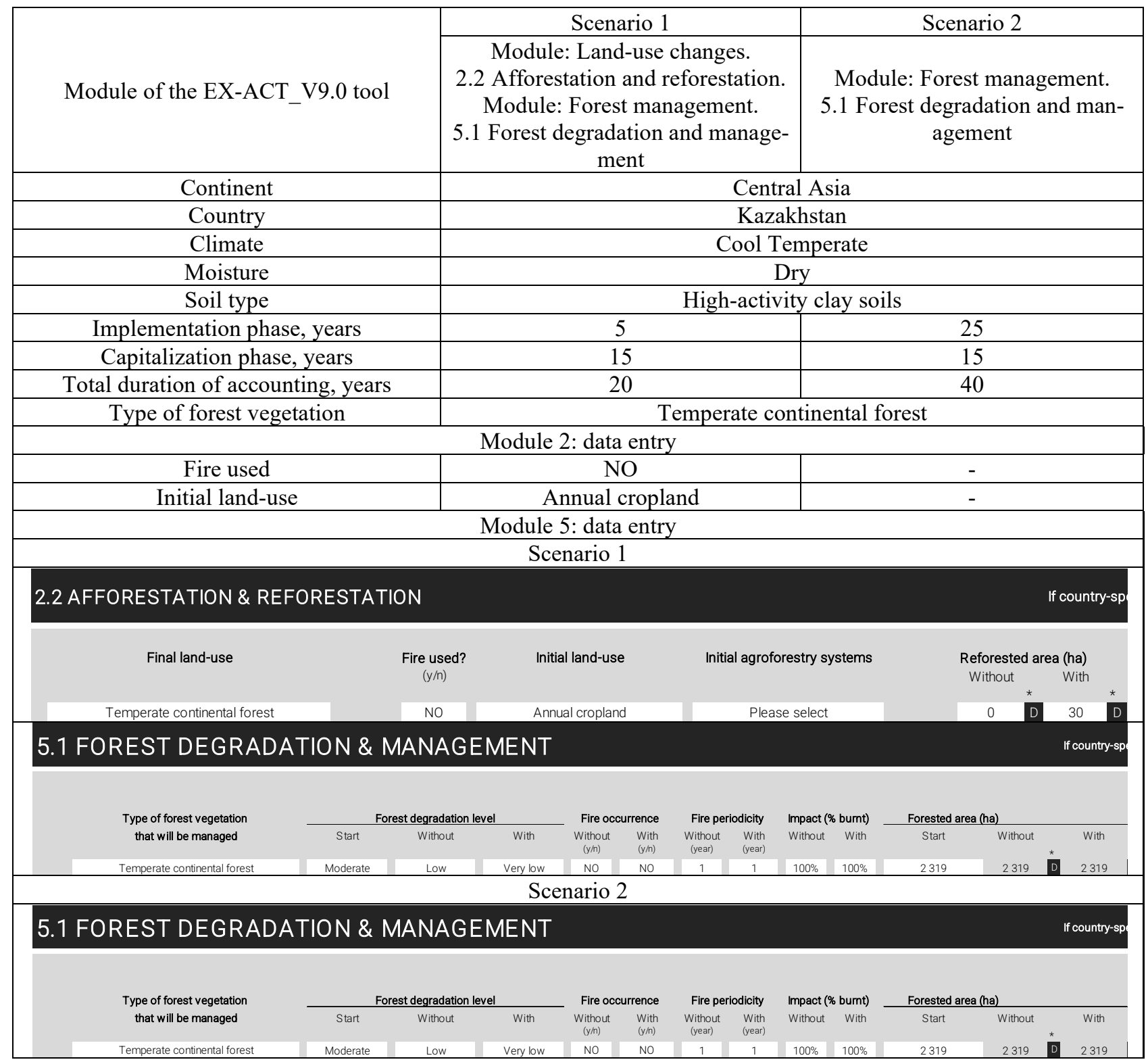

\section{Results and Discussion}

1. The oak stand parameters according to the forest inventory data

As of 01.01.2021, the forest fund total area of the West Kazakhstan region was 220 thousand ha, including the forested area of 89.7 thousands ha; the forest cover was $0.6 \%$, one of the lowest in the country [1]. In the region, the share of the most valuable natural oak stands $(Q$. robur) was diminutive. As a result of the analysis of the data on the oak forests, the West Kazakhstan region obtained from the State Enterprise "Kazakh forestry enterprise" as of 01.01.1992 and 01.01.2016, the following was established. 
In 1992, the oak forests total area on the territory of the four CSI for the protection of forests and fauna (Burlinskiy, Uralskiy, Yanvartsevskiy, and Chingirlauskiy) amounted to 2,465.9 ha (Fig. 2). As of 01.01.2016, only the first three forest owners preserved the oak forests with a total area of 2,367.2 ha, which is $2.6 \%$ of the area covered by forests in the region. On the territory of the Chingirlauskiy CSI, the oak forests were absent. It was not possible to establish the exact reason for their absence; perhaps they disappeared under the pressure from frequent droughts and wild fires. On the whole, over 24 years the total area of the oak forests decreased by 98.7 ha, or $4 \%$.

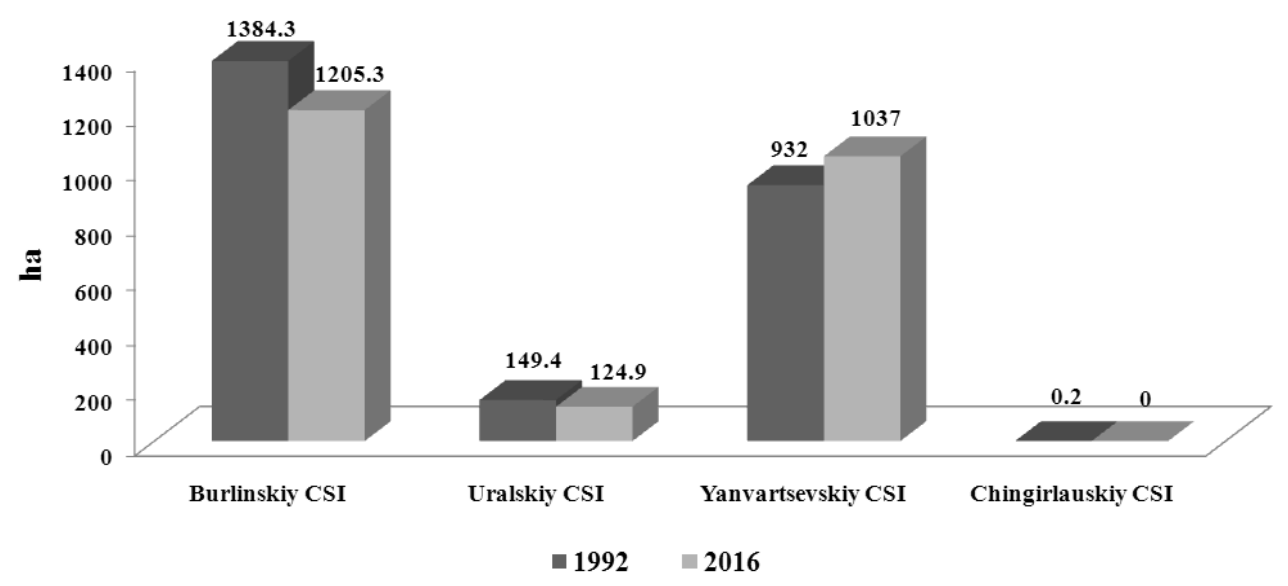

Figure 2. The distribution of the oak forests (ha) by forest owner in the West Kazakhstan region

Changes in the basal area of the oak forests were also recorded. Analysis of the distribution of the oak forests by basal area (Fig. 3) illustrated that as of 01.01.1992, stands with the 0.7 and 0.6 relative basal area dominated and accounted for $56.3 \%$ of the oak forests total area. As of 01.01 .2016 , stands with the 0.5 and 0.6 relative basal area prevailed and accounted for $64.3 \%$ of the total area of the oak forests. At the same time, the forest stands area with the 0.5 relative basal areas increased, while the oak forests area with the 0.7 basal areas decreased; that is, the tree density decreased since 1992. There were only few high-density stands (with the 0.8 basal area and above), and their area had been decreasing.

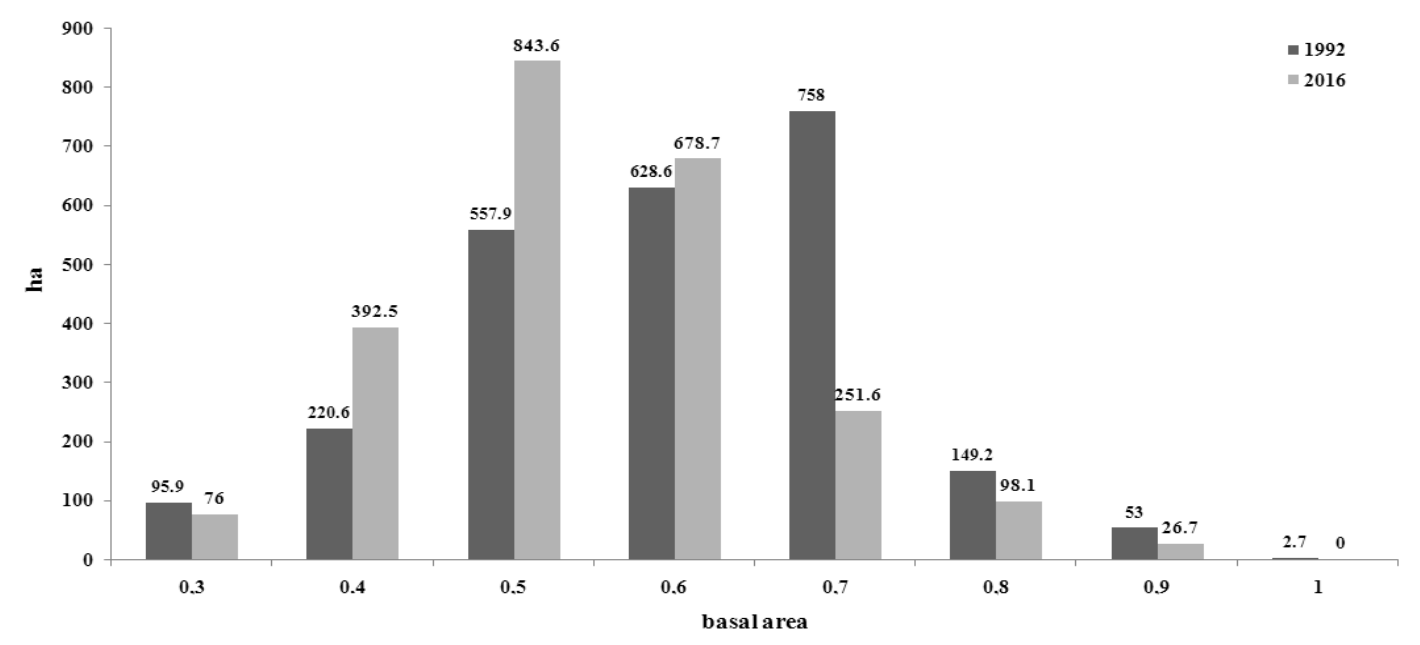

Figure 3. The distribution of the oak forests (ha) by basal area

Analysis of the distribution of the oak forests by the site productivity class (Fig. 4) revealed that as of 01.01.1992, stands of the second site productivity class predominated, which accounted for almost $50 \%$ of the oak forest area. As of 01.01.2016, oak stands of the fourth site productivity class predominated and accounted for $50.2 \%$ of the oak forest area. This indicates a decrease in the productivity of the oak forests because of deterioration of soils and changes in the climatic conditions. 
The analysis of the distribution of the oak forests by age class (taken as 10 year) showed that in 1992, stands of the sixth and seventh age classes dominated, accounting for $65 \%$ of the total area of the oak forests. Stands, younger than 60 years, accounted for $30.7 \%$, while stands, older than 70 years, - for $4.4 \%$. In 2016, stands of the seventh and eighth age classes dominated, accounting for $61.1 \%$ of the total area of the oak forests. At the same time, the younger stands area was only $8.5 \%$ of the total area of the oak forests (Fig. 5).

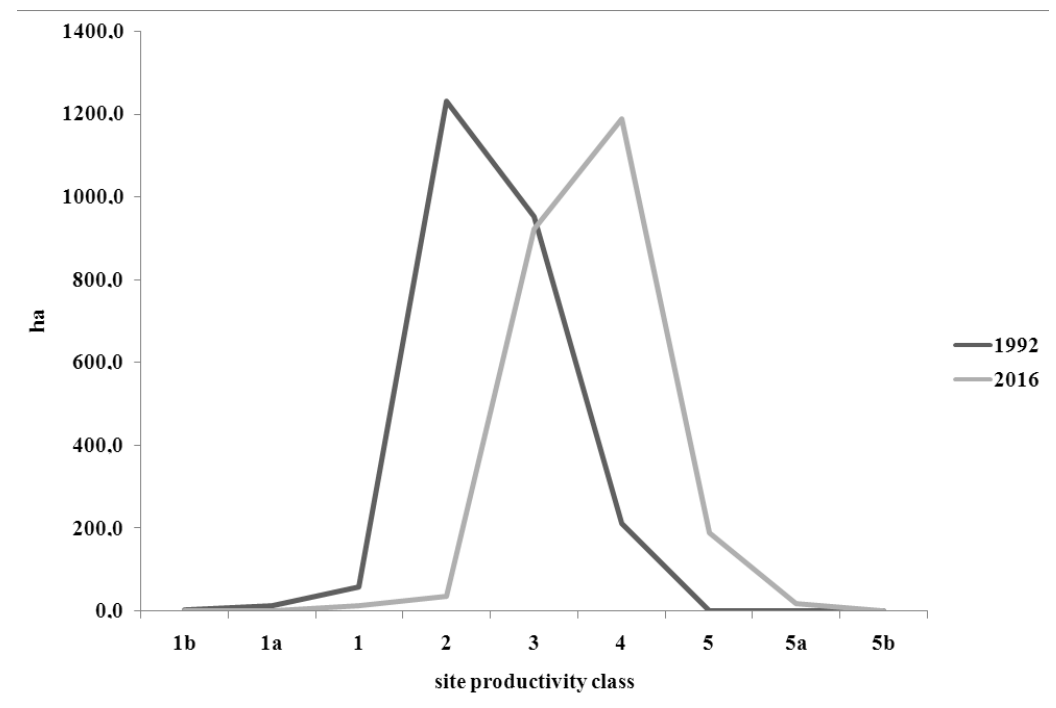

Figure 4. Distribution of the oak forests (ha) by the site productivity class

Presently, mature and over-mature oak stands prevail in the West Kazakhstan region. Changes in the distribution of stands by age class occurred as a result of natural aging and transition from one age class to another, and because of anthropogenic factors, including forest fires. It should be noted that seed regeneration of broad-leaved species, including $Q$. robur, is suppressed at the extreme limit of their natural distribution range due to weakened seed production, intensive development of herbaceous plants in low density stands, and anthropogenic impact. However, owing to reproduction through re-sprouting, forest-forming species can regenerate and are able to persist in the occupied area [6]. This is also observed in the floodplain forests of the region, where the oak forests reproduced through re-sprouting dominate [38] and occupy about $80 \%$ of the oak forest area [29].

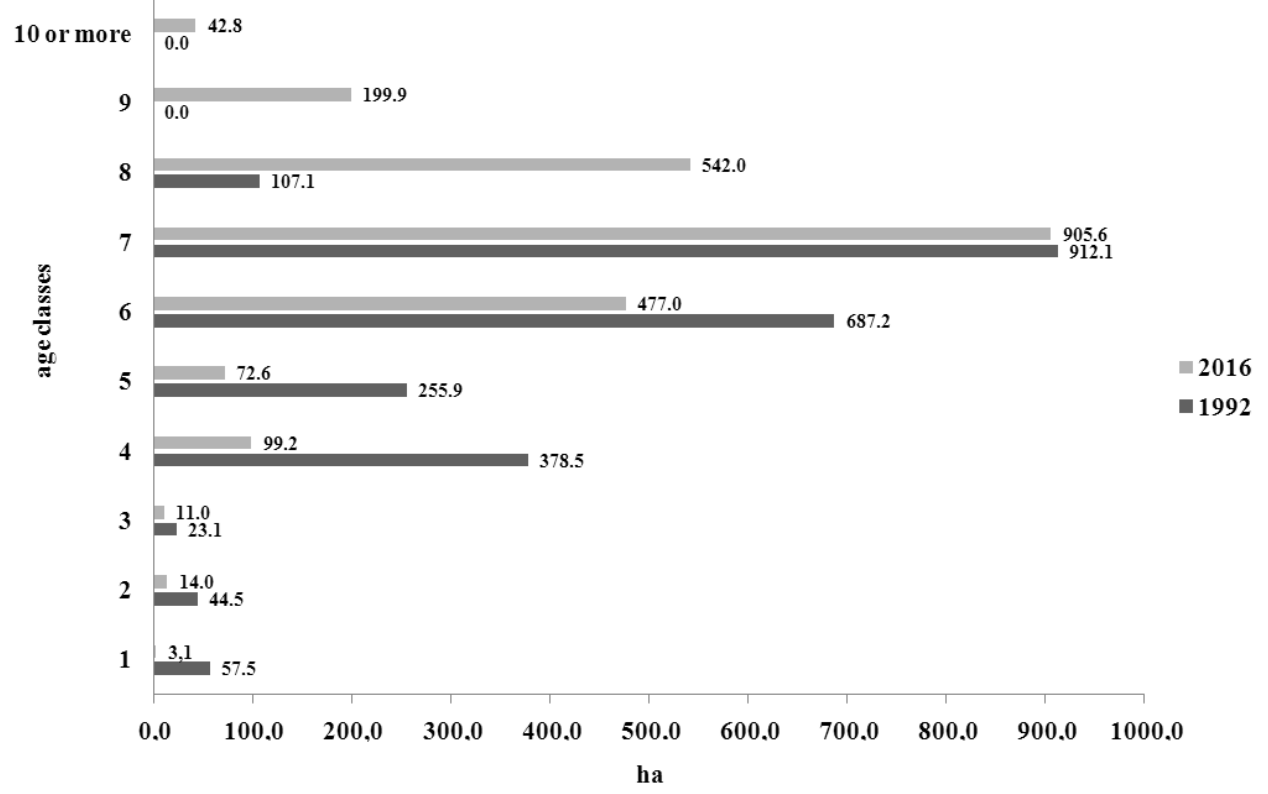

Figure 5. The distribution of the oak forests (ha) by age classes 
Thus, the results of our analysis of the forest inventory data on the oak forests of the West Kazakhstan region for 1992-2016 indicate a decrease in the area occupied by $4 \%$ of $Q$. robur, a decrease in stand density and site productivity, as well as the prevalence of mature and over-mature stands reproduced through resprouting.

2. The oak forests' current state according to the sample plot surveys results

To obtain the detailed information on the oak forests' current state, we carried out surveys of five sample plots in the middle reaches of the Ural River valley in 2021. The sample plots layout is demonstrated in Figure 6.

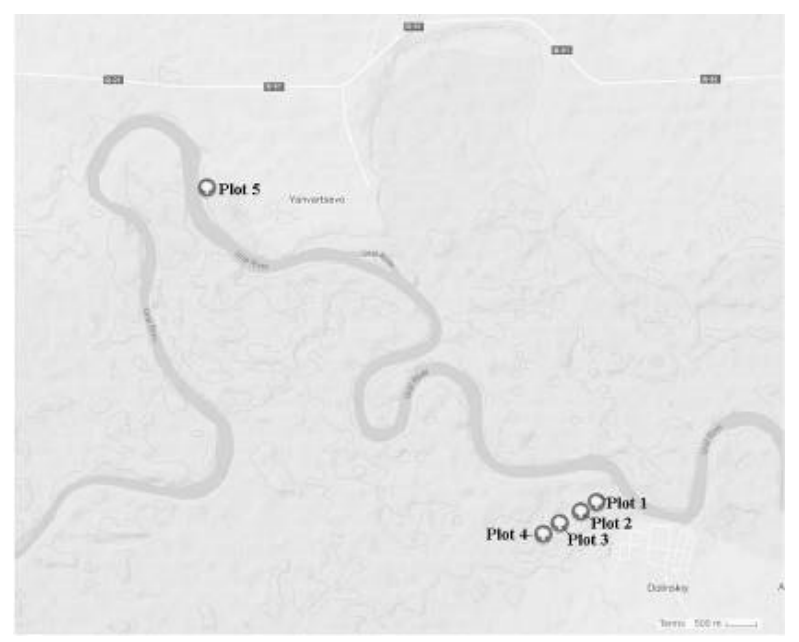

Figure 6. The sample plots layout

The surveyed oak stands were represented mainly by low-density, pure stands of the sixth and seventh age classes (Tab. 2, Fig. 7a). Some stands had an insignificant admixture of Ulmus laevis Pall., Populus al$b a$ L., and Acer negundo L. Our data are in good agreement with the results of the analysis of the forest inventory materials (see the previous sub-section). Natural regeneration of $Q$. robur (Fig. $7 b$ ) was recorded in small quantities in one plot (sample plot 1) only. The presence of the invasive species Acer negundo L. in all sample plots designates an anthropogenic impact and can lead to undesirable changes in species composition. Lately, several authors have pointed to this problem [9].

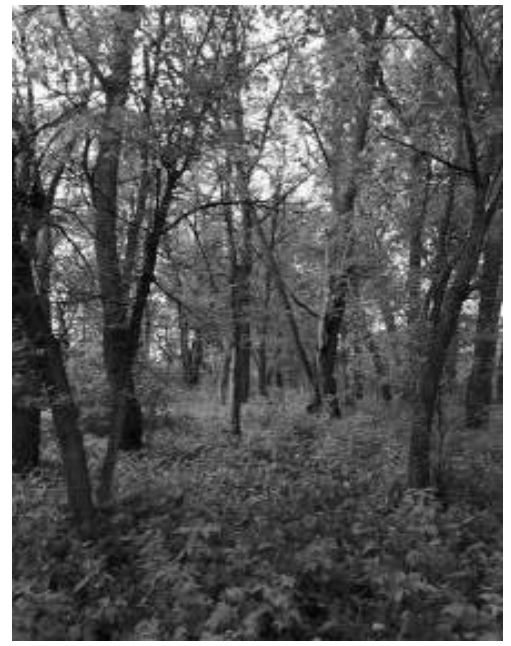

$a$

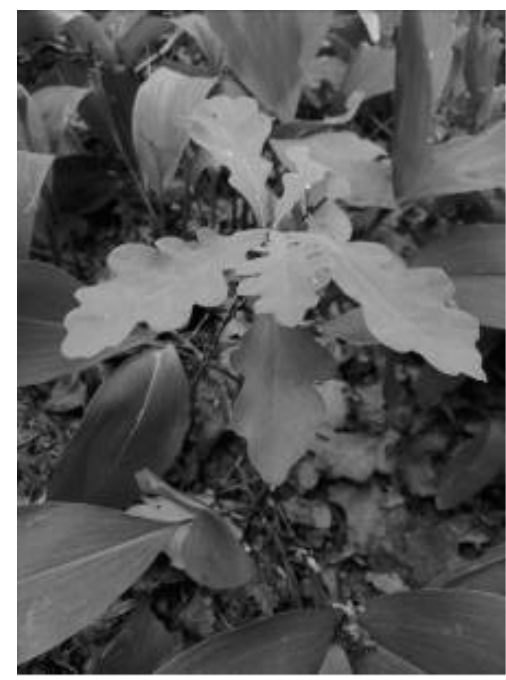

$b$

$a$ - general view of the sample plot $1 ; b$ - natural regeneration of $Q$. robur

Figure 7. An oak stand 


\begin{tabular}{|c|c|c|c|c|c|c|}
\hline \multirow{11}{*}{ 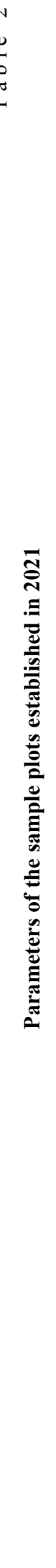 } & 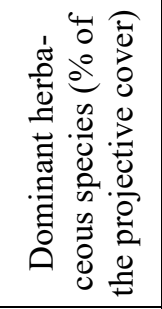 & 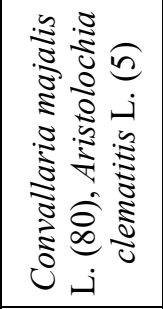 & 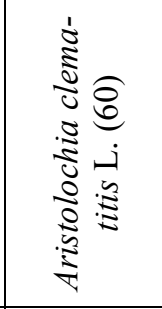 & 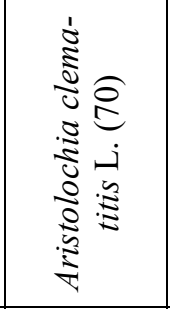 & 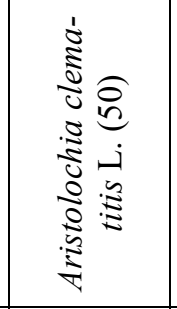 & 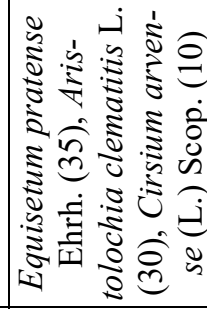 \\
\hline & 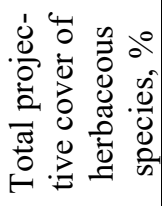 & \& & 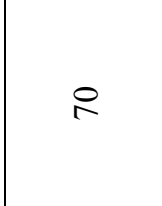 & \& & 8 & $\tilde{a}$ \\
\hline & 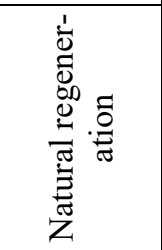 & 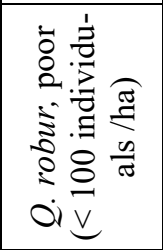 & $\begin{array}{l}\overrightarrow{0} \\
\text { D. } \\
\text { त् }\end{array}$ & 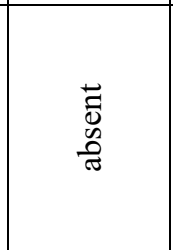 & $\begin{array}{l}\overrightarrow{0} \\
\text { D } \\
\text { है }\end{array}$ & $\begin{array}{l}\overrightarrow{\widetilde{0}} \\
\text { Dे } \\
\vec{\sigma}\end{array}$ \\
\hline & 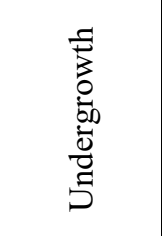 & 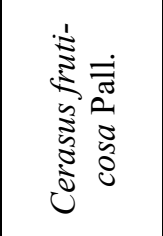 & 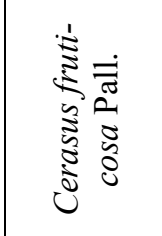 & 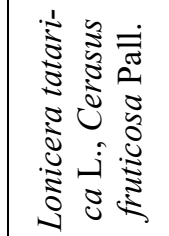 & 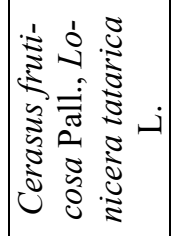 & 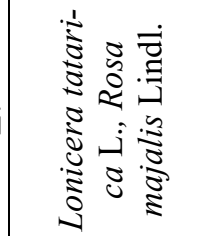 \\
\hline & 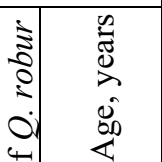 & $\stackrel{R}{R}$ & 8 & 8 & 8 & 8 \\
\hline & 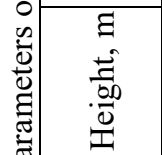 & $\stackrel{\circ}{\stackrel{1}{2}}$ & $\stackrel{n}{\simeq}$ & $\stackrel{\circ}{\stackrel{.}{I}}$ & $\stackrel{\circ}{\stackrel{ }{I}}$ & $\ddot{n}$ \\
\hline & 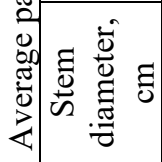 & 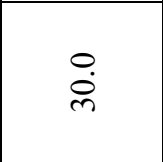 & ㄹ. & $\begin{array}{l}\dot{0} \\
\stackrel{\sim}{\sim}\end{array}$ & $\begin{array}{l}n \\
\infty \\
\sim \\
\sim\end{array}$ & $\stackrel{\widetilde{H}}{\mathscr{f}}$ \\
\hline & 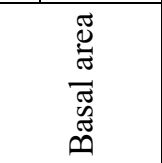 & $\stackrel{\infty}{\circ}$ & $\tilde{o}$ & $\tilde{0}$ & $\tilde{o}$ & $\tilde{o}$ \\
\hline & 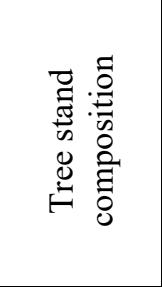 & 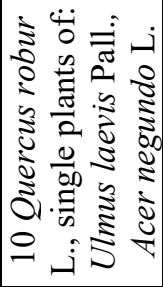 & 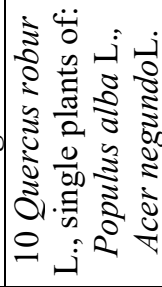 & 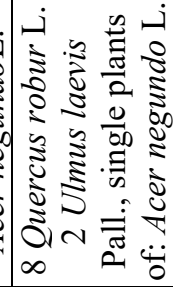 & 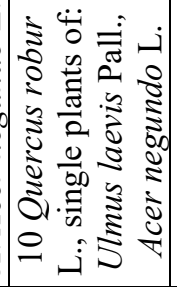 & 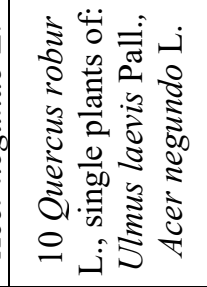 \\
\hline & 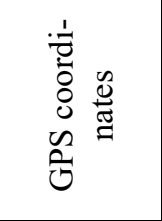 & 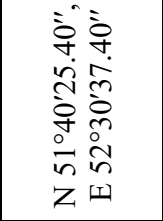 & 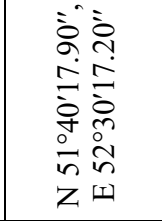 & 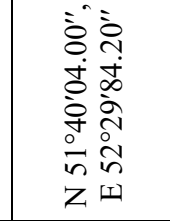 & 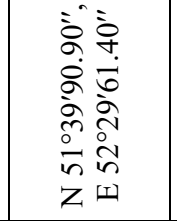 & 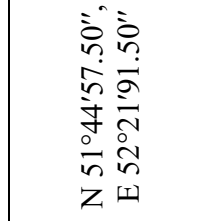 \\
\hline & 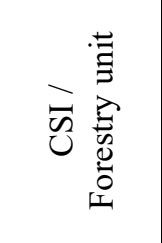 & 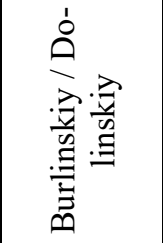 & 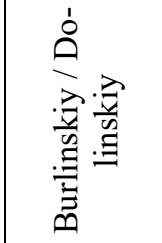 & 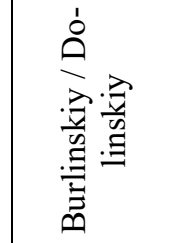 & 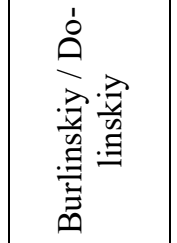 & 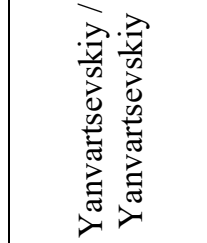 \\
\hline
\end{tabular}


The undergrowth contains mainly Lonicera tatarica L. and Cerasus fruticosa Pall., and less often, Rosa majalis Lindl.

The grass layer was abundant with a total projective cover of $60-90 \%$, but poor in floristic diversity. Only one sample plot was dominated by an early flowering mesophilic forest species Convallaria majalis L. (Fig. 8a). In other areas, Aristolochia clematitis L. is predominated (Fig. 8b). Although it is also an element of the mesophilic forest flora, it is less valuable in phytocenotic terms.

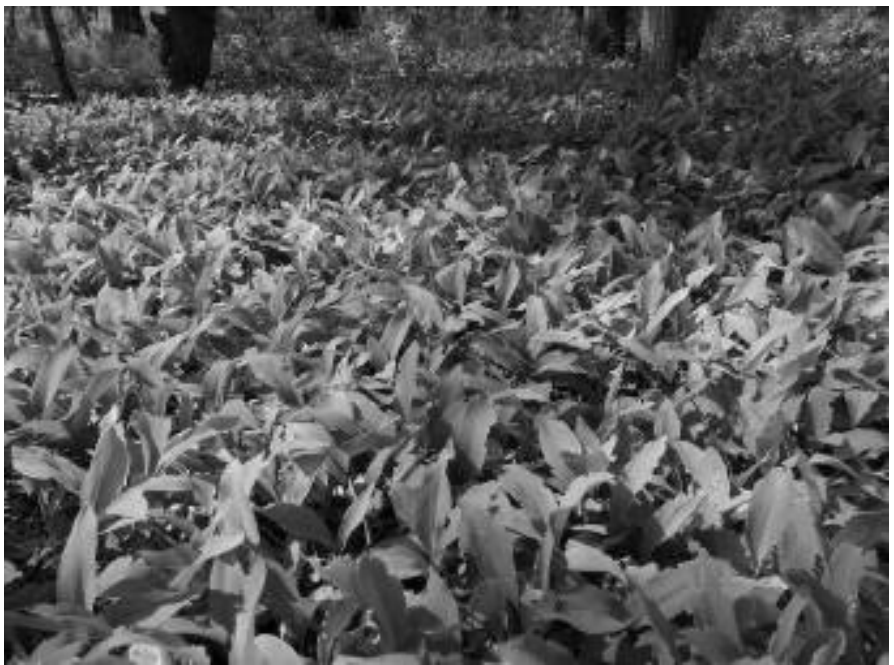

$a$

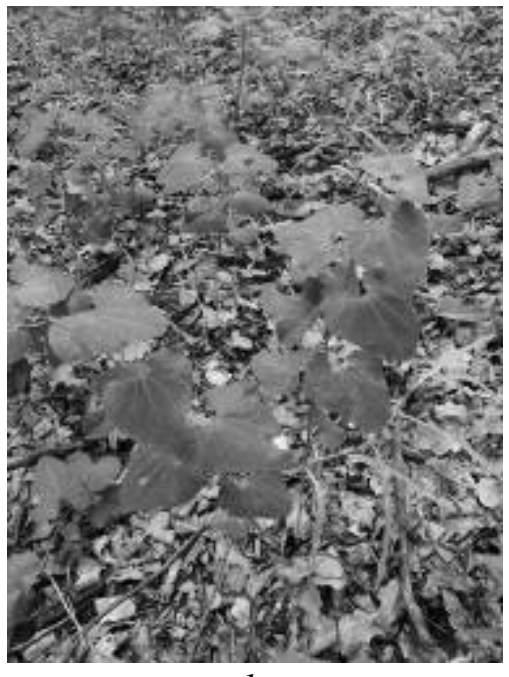

$b$

$a-$ Convallaria majalis L.; $b$-Aristolochia clematitis $\mathrm{L}$.

Figure 8. The dominant herbaceous species of the oak forests

P.L. Gorchakovskii [8] commented on a poor and uniform floristic composition and simplified structure of the oak forests in the Ural River valley. According to B.A. Bykov, Convallaria majalis L. and Aristolochia clematitis L. are typical representatives of the herbaceous cover of the European forests; they penetrated into the territory of Kazakhstan together with $Q$. robur [4]. The oak forest with Convallaria majalis is considered the most widespread oak forest in the region [9]. At the same time, oak forests with Convallaria majalis L., Euonymus verrucosus Scop., and Corylus avellana L. are listed as relict [7] and require special protection. It should be noted that such rare species as Corylus avellana L., Euonymus verrucosus Scop., and Convallaria majalis L. are listed in the Red Data Book of Kazakhstan [3].

In 1980, proposal for the need to preserve the unique flora and vegetation of the region was made to create a nature reserve encompassing floodplain poplar and oak forests and meadows [39]. The proposal has not yet been implemented but is still relevant.

3. Carbon balance

Forests contribute to climate change mitigation by absorbing $\mathrm{CO}_{2}$ and using it to form aboveground and underground biomass, and to replenish soil carbon. To develop proposals for improving the environmental conditions in the region, we carried out calculations of the carbon balance using various scenarios. According to Scenario 1, the carbon balance was calculated for the oak forests with an area of 2,348.5 ha, which included forest stands of 3-5 ha site productivity classes and future forest plantations (Fig. 9, Tab. 3).

T a b l e 3

Carbon potential of oak forest management in Western Kazakhstan

\begin{tabular}{|c|c|c|c|}
\hline Type of activity & Area, ha & $\begin{array}{c}\mathrm{CO}_{2} \text {-equivalent, ton } \\
\text { (with interventions) }\end{array}$ & $\begin{array}{c}\mathrm{CO}_{2} \text {-equivalent, } \\
\text { ton / year / ha } \\
\text { (with interventions) }\end{array}$ \\
\hline Silvicultural & 30.0 & 12723 & 21.2 \\
\hline Forestry & 2318.5 & 359406 & 7.75 \\
\hline Total & 2348.5 & 372128 & 7.9 \\
\hline
\end{tabular}




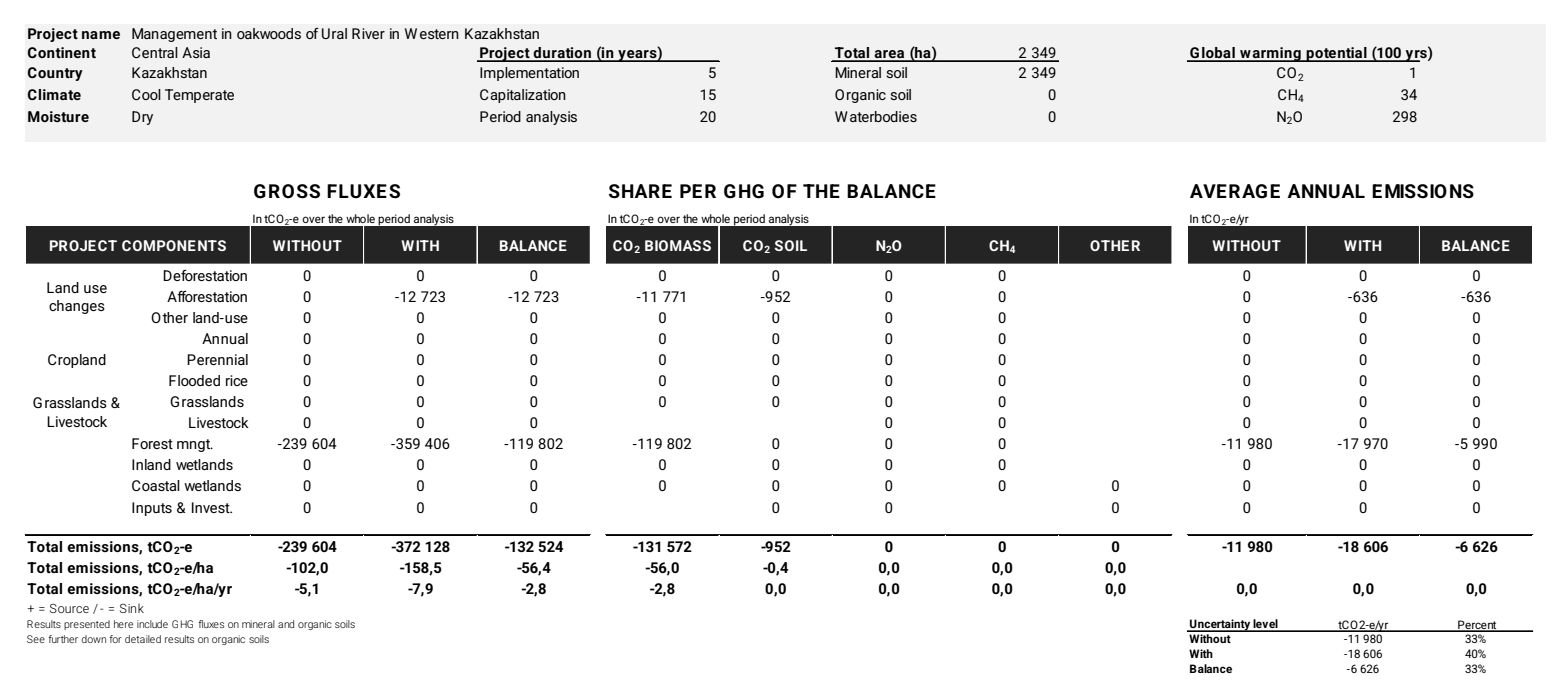

Figure 9. Results of calculating the carbon balance according to Scenario 1

Without project interventions, the carbon balance for the reporting period (20 years) will be 0.24 million tons of $\mathrm{CO}_{2}$-equivalent or $5.1 \mathrm{CO}_{2}$-equivalent/ha/year. Thus, the additional net carbon uptake achieved as a result of the implementation of the measures will amount to 2.8 tons of $\mathrm{CO}_{2}$-equivalent/ha/year.

Data on the average and total growing stock per hectare of the oak forests in the floodplain of the Ural River, obtained between 1992 and 2016, demonstrate the degradation dynamics (Tab. 4).

Table 4

The oak forests development in Kazakhstan between 1992 and 2016

\begin{tabular}{|c|c|c|c|c|c|}
\hline \multirow{2}{*}{ Indicators } & Measurement & \multicolumn{2}{|c|}{ Period } & \multicolumn{2}{c|}{ Difference } \\
\cline { 3 - 6 } & unit & 1992 & 2016 & $\mathrm{~m}^{3}$ & $\%$ \\
\hline Total growing stock & $1000 \mathrm{~m}^{3}$ & 303.4 & 292.5 & -10.9 & 3.6 \\
\hline Increment / ha & $\mathrm{m}^{3}$ & 1.8 & 1.8 & 0.0 & 0 \\
\hline Growing stock / ha & $\mathrm{m}^{3}$ & 123 & 124 & -1 & -0.8 \\
\hline
\end{tabular}

An average annual growth rate of about $1.8 \mathrm{~m}^{3}$ per hectare is considered low. The results of calculating the carbon balance according to Scenario 2 are presented in Figure 10 and Table 5.

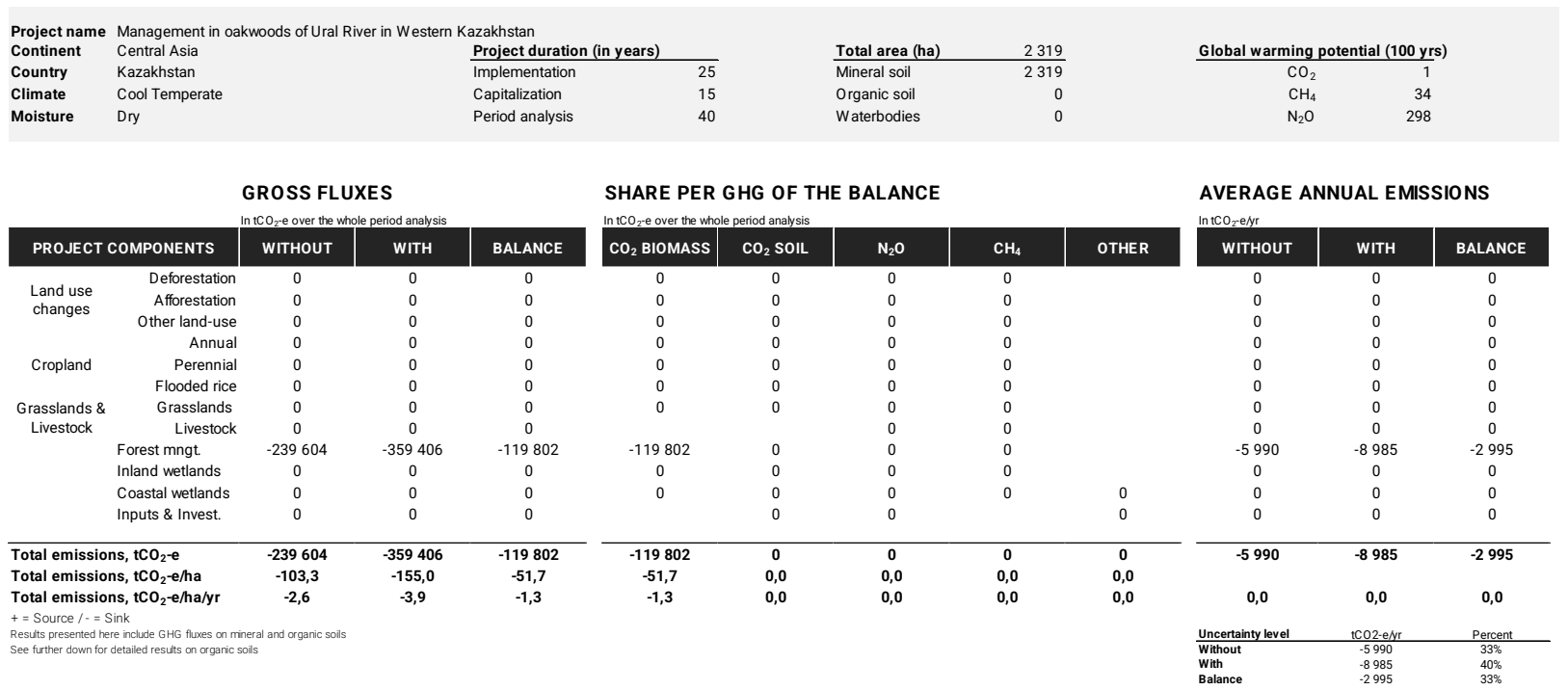

Figure 10. Results of calculating the carbon balance according to Scenario 2 
Carbon streams with and without project activities

\begin{tabular}{|c|c|c|c|}
\hline $\begin{array}{c}\text { Type of activity } \\
\text { Reducing degradation }\end{array}$ & $\begin{array}{c}\mathrm{CO}_{2} \text {-equivalent, ton } \\
\text { (without the project) }\end{array}$ & $\begin{array}{c}\mathrm{CO}_{2} \text {-equivalent, ton } \\
\text { (with the project) }\end{array}$ & Balance \\
\hline Total emissions & 239604 & 359406 & 119802 \\
\hline Per hectare & 103.3 & 155.0 & 51.7 \\
\hline Per hectare / year & 2.6 & 3.9 & 1.3 \\
\hline
\end{tabular}

With a decrease in forest degradation, the net carbon uptake (ha/year) will be 3.9 tons of $\mathrm{CO}_{2}$ equivalent, which will provide an average potential. Thus, sustainable forest management allows for a positive carbon balance in the future.

\section{Conclusions}

According to the data from "Kazakh Forest Management Enterprise", the oak forests occupy 2367.2 hectares in the West Kazakhstan region, which is $2.6 \%$ of the all forested area in the region. In 1992-2016, the area of oak forests decreased by 98.7 hectares, or $4 \%$. The analysis of the forest inventory data illustrated the negative dynamics of the oak forests: the decrease of stand density and site productivity, and the predominance of mature and over-mature stands reproduced through re-sprouting.

The above results are consistent with the results of our field studies. A characteristic feature of the surveyed oak forests is a poor natural regeneration and a relatively low floristic diversity, which can be explained by the unfavorable conditions of their existence at the border of the natural distribution range. The presence of an invasive species Acer negundo L. in all sample plots indicates the potential undesirable change in the species composition leading to the displacement of the most valuable species.

In view of the paramount ecological role of the oak forests, the reduction of their areas, and poor natural regeneration, we emphasize the need for the special protection and further study of the oak forests, primarily through the development of measures to promote the natural regeneration of $Q$. robur and the creation of sustainable forest plantations.

One of the main ways to preserve the oak forests in the face of climate change is sustainable forest management. Rational management decisions will ensure a positive carbon balance in the oak forests of the West Kazakhstan region.

To preserve the relict forests of the Ural River floodplain, including the oak forests with their biological diversity and rare floristic elements, it is necessary to create a specially protected natural area, which will reduce the negative impact of such anthropogenic factors as felling, recreation, grazing, and wild fires.

\section{Acknowledgements}

This research is funded by the Ministry of Ecology, Geology and Natural Resources of the Republic of Kazakhstan (No. BP10263776). The authors express their gratitude to the RSTE "Kazakh Forest Management Enterprise" for providing forest management materials; Burlinskiy and Yanvartsevskiy Communal State Institutions for the protection of forests and wildlife of the Department of Natural Resources and Environmental Management of the West Kazakhstan region for assistance in establishing sample plots; FAO Partnership and Liaison Office in the Republic of Kazakhstan for providing training in using the FAO Preliminary Carbon Balance Assessment Tool (EX-ACT) to estimate potential reduction in greenhouse gas emissions.

\section{References}

1 Справка о состоянии и динамике лесного фонда Республики Казахстан по состоянию на 01.01.2021 г. — Алматы: Казах. лесохоз. предпр., 2021. - 80 с.

2 Токарев А.Д. Типы пойменных лесов реки Урал / А.Д. Токарев // Лесное хозяйство и агромелиорация в Казахстане. Вып. IX. - Алма-Ата: Кайнар, 1975. - С. 266-278.

3 Красная Книга Казахстана. - Т. 2. Растения. - Астана: Art Print XXI, 2014. - 452 с.

4 Быков Б.А. Вводный очерк флоры и растительности Казахстана / Б.А. Быков. — Алма-Ата: Наука, 1966. — 164 с.

5 Гудочкин М.В. Леса Казахстана / М.В. Гудочкин, П.С. Чабан. - Алма-Ата: Казгосиздат, 1958. — 324 с. 
6 Никитин С.А. Причины усыхания лесов в пойме низовья р. Урал / С.А. Никитин // Лесоведение. — 1975. — № 6. — C. $66-69$.

7 Воробьев А.И. Тополевые леса поймы р. Урал и их возобновление / А.И. Воробьев // Лесные экосистемы в условиях континентального климата. — Красноярск: Изд-во Краснояр. ун-та, 1987. — С. 43-48.

8 Горчаковский П.Л. Растения европейских широколиственных лесов на восточном пределе их ареала / П.Л. Горчаковский. - Свердловск, 1968. — 207 с.

9 Пугачев П.Г. Геоботаническая характеристика дубовых и вязовых лесов поймы среднего течения реки Урал: автореф. дис. ... канд. биол. наук / П.Г. Пугачев. - Свердловск, 1967. — 23 с.

10 Агелеуов Е.А. Флора поймы реки Урал / Е.А. Агелеуов. - Алма-Ата: Наука, 1987. - 104 с.

11 Гимадиева Ф.Х. Пойменные леса Урала в пределах степной зоны Приуралья: автореф. дис. ... канд. биол. наук / Ф.Х. Гимадиева. - Оренбург, 2002. - 24 с.

12 Рябинина 3.Н. Лесная растительность в пойме реки Урал / 3.Н. Рябинина, Ф.Х. Гимадиева. — Оренбург: Университет, 2014. $-145 \mathrm{c}$.

13 Дарбаева Т.Е. Исторический анализ флоры пойменных лесов бассейна реки Урал в пределах Западно-Казахстанской области / Т.Е. Дарбаева, Б. Альжанова, С.Н. Бохрова, О.Н. Чукалина // Вестн. Каз. нац. ун-та. Сер. биол. — 2016. — Т. 69 , № 4. - С. 32-40.

14 Елекешева М.М. Рост, строение и продуктивность пойменных насаждений реки Урал Западно-Казахстанской области: автореф. дис. ... канд. сел.-хоз. наук / М.М. Елекешева. — М., 2020. — 22 с.

15 Padalko Y.A. Problems of riverbed evolution in the basin of the Ural River / Y.A. Padalko, A.A. Chibilyov // Doklady Earth Sciences. — 2017. — Iss. 475. — P. 968-971. https://doi.org/10.1134/S1028334X17080268

16 Tulemisova G. Ecological state of the river Ural / G. Tulemisova, R. Abdinov, G. Kabdrakhimova, T. Janetov // Chemical Bulletin of Kazakh National University. - Vol. 85, No. 2. - P. 18-24. https://doi.org/10.15328/cb808

17 Padalko Y.A. An assessment and prognosis of water resources use in regions of the transboundary basin of the Ural River in the medium term / Y.A. Padalko // IOP Conference Series: Earth and Environmental Science. — 2021. — Vol. 817. — ID Article 012080. https://doi.org/10.1088/1755-1315/817/1/012080

18 Čater M. A 20-year overview of Quercus robur L. mortality and crown conditions in Slovenia / M. Čater // Forests. — 2015. — No. 6. - P. 581-593. https://doi.org/10.3390/f6030581

19 Trudić B. Conservation of Quercus robur L. genetic resources in its south-eastern refugium using SSR marker system - a case study from Vojvodina province, Serbia / B. Trudić, E. Avramidou, B. Fussi, C. Neophytou, S. Stojnić, A. Pilipović // Austrian Journal of Forest Science. - 2021. - Vol. 138, No. 2. - P. 117-140.

20 Селочник Н.Н. Многолетняя динамика старовозрастных насаждений Теллермановских дубрав / Н.Н. Селочник // Лесоведение. - 2017. - № 2. - С. 59-68.

21 Skiadaresis G. Groundwater extraction in floodplain forests reduces radial growth and increases summer drought sensitivity of pedunculate oak trees (Quercus robur L.) / G. Skiadaresis, J.A. Schwarz, J. Bauhus // Frontiers in Forests and Global Change. 2019. — Vol. 2; Article 5. https://doi.org/10.3389/ffgc.2019.00005

22 Bernoux M. Ex-ante greenhouse gas balance of agriculture and forestry development programs / M. Bernoux, G. Branca, A. Carro, L. Lipper, G. Smith, L. Bockel // Scientia Agricola. - 2010. - Vol.67, No. 1. - P.31-40. https://doi.org/10.1590/s0103-90162010000100005

23 Bernoux M. Ex-Ante Carbon balance Tool (EX-ACT) - Technical Guidelines. Easy Pol module, 218 / M. Bernoux, L.-S. Schiettecatte, M. Tinlot, L. Bockel, G. Branca, A. Gentien, V. Colomb. - Rome: FAO, 2014. - 18 p.

24 Bockel L. Ex-Ante Carbon-balance Tool for Value Chain (EX-ACT VC) (Guidelines) / L. Bockel, O. Debrune, A. Toudert, E. Doro, O. Lozada, L.-S. Schiettecatte. - Rome: FAO, 2017. — 24 p.

25 Seddon N. Nature-based Solutions in Nationally Determined Contributions: Synthesis and recommendations for enhancing climate ambition and action by 2020 / N. Seddon, S. Sengupta, M. García-Espinosa, I. Hauler, D. Herr, A.R. Rizvi. - Gland, Switzerland and Oxford, UK: IUCN and University of Oxford, 2019. - $120 \mathrm{p}$.

26 Стратегический план Министерства экологии, геологии и природных ресурсов Республики Казахстан на 20202024 гг. Утв. приказом Министерства экологии, геологии и природных ресурсов Республики Казахстан от 14 января 2020 г. $35 \mathrm{c}$.

27 Сводный проект организации и развития лесного государства Западно-Казахстанской области. — Алматы, 1993.

28 Сводный лесоустроительный проект по Западно-Казахстанской области. (Пояснительная записка). — Алматы: Казах. лесохоз. предпр., 2018. - 110 с.

29 Chashina B. Natural recreation potential of the West Kazakhstan region of the Republic of Kazakhstan / B. Chashina, N. Ramazanova, E. Atasoy, Z. Berdenov, D.C. Ilieș // Geo Journal of Tourism and Geosites. — 2020. — Vol. 32, No. 4. - P. 13551361. https://doi.org/10.30892/gtg.32424-580

30 Gebrehiwot K. Species composition, plant Community structure and natural regeneration status of Belete Moist Evergreen Montane Forest, Oromia Regional state, Southwestern Ethiopia / K. Gebrehiwot, K. Hundera // Momona Ethiopian Journal of Science. — 2014. - Vol. 6, No. 1. - P. 97-101. https://doi.org/10.4314/mejs.v6i1.102417

31 Mchenga I.S. Natural regeneration of mangroves in a degraded and non-degraded tropical forest of Zanzibar Island / I.S. Mchenga, A.I. Ali // Journal of Global Biosciences. — 2014. — Vol. 3, No. 1. — P. 334-344. 
32 Понятовская В.М. Учет обилия и особенности размещения видов в естественных растительных сообществах / В.М. Понятовская // Полевая геоботаника. — М.-Л.: Наука, 1964. — Т. 3. - С. 209-299.

33 Флора Казахстана. - Т. 1-9. - Алма-Ата: Наука, 1956-1966.

34 International Plant Names Index. Published on the Internet http://www.ipni.org. The Royal Botanic Gardens, Kew, Harvard University Herbaria \& Libraries and Australian National Botanic Gardens.

35 Bockel L. EX-ACT user manual: estimating and targeting greenhouse gas mitigation in agriculture. / L. Bockel, U. Grewer, C. Fernandez, M. Bernoux. - Rome: FAO, 2013. - 11 p.

36 Grewer U. EX-ACT quick guidance manual: estimating and targeting greenhouse gas mitigation in agriculture / U. Grewer, L. Bockel, M. Bernoux. - Rome: FAO, 2013. - 14 p.

37 Kehayova E. Report on options for nature-based solutions to enhance NDC commitments in three countries (Kazakhstan, Kyrgyzstan and Tajikistan). Technical and financial analysis of promising nature-based solutions for climate change / E. Kehayova, B. Mislimshoeva, G. Abdurasulova, B. Wippel. — Dushanbe: Deutsche Gesellschaft für Internationale Zusammenarbeit (GIZ) Gmb, 2020. $-45 \mathrm{p}$.

38 Бессчетнов П.П. Редкие и ценные растения Казахстана. Деревья и кустарники / П.П. Бессчетнов, С.Н. Мальцев. Алма-Ата: Кайнар, 1981. - 223 с.

39 Быков Б.А. Охрана ботанических объектов в Казахстане / Б.А. Быков, С.А. Арыстангалиев // Охрана редких видов растений и растительности Казахстана. - Алма-Ата: Наука, 1987. — С. $20-42$.

\author{
В.Ю. Кириллов, В.П. Алека, А.А. Иващенко, А.Н. Рақымжанов, \\ Н.С. Келгенбаев, Д.У. Әуезов, Г.С. Айтеков, Т.Н. Стихарева
}

\title{
Жайық өзені жайылмасындағы (Батыс Қазақстан облысы) емен ормандарының қазіргі жағдайы және олардың тұрақты даму келешегі
}

\begin{abstract}
Мақалада орман шаруашылығының материалдарын талдау (01.01.1992 ж. және 01.01.2016 ж.) және авторлардың далалық зерттеулері негізінде Жайық өзені (Батыс Қазақстан облысы) жайылмасындағы емен ормандарының қазіргі жағдайын көрсететін мәліметтер келтірілген. Жайылмалы ормандар арасындағы ең берік екпелер ретінде емен ормандарының экологиялық маңыздылығына байланысты Quercus robur L.-тен тұратын ормандардың жай-күйінің динамикасын зерттеу ғылыми зерттеулердің өзекті бағыты болып табылады, ареалдың оңтүстік-шығысында олардың биологиялық әртүрлілігін сақтау қажеттілігі туындайды. 24 жылдық кезеңде аймақтағы емен ағаштарының ауданы 98,7 га, яғни 4 \%-ға қысқарғаны анықталды. Сүрекдіңнің сиреуі, оның бонитетінің төмендеуі, жоғары жастағы сүрекдіңдердің басым болуы үдерістері атап өтілді. Сүрекдіңнің түрлік құрамы бойынша таза емен ормандары басым немесе Ulmus laevis Pall., Populus alba L., Acer negundo L. шамалы қоспасы бар. Q. robur табиғи жаңаруы қанағаттанарлықсыз немесе мүлдем жоқ. Шөптер жалпы проекциялық жамылғының жоғары көрсеткіштеріне ие (90 \% дейін), бірақ флористикалық құрамы нашар. ЕХ-АСТ құралын қолдана отырып, әртүрлі басқару сценарийлерінде емен ормандарындағы көміртегі балансының болжамы келтірілген. Осы бірегей ормандарды сақтауға, соның ішінде Q. robur табиғи жаңаруына жәрдемдесу және тұрақты орман дақылдарын құруға бағытталған іс-шараларды әзірлеу қажеттілігі атап өтілді. Емен ормандарына антропогендік факторлардың әсерін азайту үшін (ағаш кесу, мал жаю, рекреация және т.б.) аймақта ерекше қорғалатын табиғи аумақ құру ұсынылды.
\end{abstract}

Кілm сөздер: Quercus robur L., жайылма орман, бонитет, жас құрамы, сүрекдіңнің толымдылығы, табиғи жаңару, ЕX-АCT, антропогендік әсер.

\section{В.Ю. Кириллов, В.П. Алека, А.А. Иващенко, А.Н. Рахимжанов, Н.С. Келгенбаев, Д.У. Ауезов, Г.С. Айтеков, Т.Н. Стихарева \\ Современное состояние дубрав в пойме реки Урал (Западно-Казахстанская область) и перспективы их устойчивого развития}

В статье приведены сведения, отражающие современное состояние дубрав поймы р. Урал (ЗападноКазахстанская область) на основе анализа лесоустроительных материалов (на 01.01.1992 г. и 01.01.2016 г.) и полевых обследований авторов. Изучение динамики состояния лесов из Quercus robur L. является актуальным направлением научных исследований ввиду важного экологического значения дубрав как наиболее долговечных насаждений среди пойменных лесов, необходимости сохранения их биологического разнообразия на юго-востоке ареала. Установлено, что за 24-летний период площадь дубрав в регионе сократилась на 98,7 га, т.е. на $4 \%$. Отмечены процессы изреживания древостоя, снижения его бонитета, преобладания высоковозрастных древостоев, преимущественно порослевого происхождения. По видовому составу древостоя преобладают чистые дубняки либо с незначительной 
примесью Ulmus laevis Pall., Populus alba L., Acer negundo L. Естественное возобновление Q. robur неудовлетворительное или вообще отсутствует. Травостой с высокими показателями общего проективного покрытия (до 90 \%), однако бедный по флористическому составу. Приведен прогноз баланса углерода в дубравах при различных управленческих сценариях с применением инструмента EX-ACT. Отмечена необходимость разработки мероприятий, направленных на сохранение этих уникальных лесов, в том числе по содействию естественному возобновлению $Q$. robur и созданию устойчивых лесных культур. Для снижения влияния на дубравы антропогенных факторов (порубки, выпас скота, рекреация и др.) предложено создать в регионе особо охраняемую природную территорию.

Ключевые слова: Quercus robur L., пойменный лес, бонитет, возрастной состав, полнота древостоя, естественное возобновление, ЕХ-АCT, антропогенное воздействие.

\section{References}

1 Spravka o sostoianii i dinamike lesnogo fonda Respubliki Kazakhstan po sostoianiiu na 01.01.2021 g. [Information on the status and dynamics of the forest fund of the Republic of Kazakhstan as of 01.01.2021]. (2021). Almaty: Kazakh Forest Management Enterprise [in Russian].

2 Tokarev, A.D. (1975). Tipy poimennykh lesov reki Urala [Types of floodplain forests of the Ural River]. Lesnoe khoziaistvo $i$ agrolesomelioratsiia $v$ Kazakhstane - Forestry and agroforestry in Kazakhstan. (Issue IX). Alma-Ata: Kainar [in Russian].

3 Krasnaia kniga Kazakhstana. T. 2. Rasteniia [The Red Data Book of Kazakhstan. Vol. 2. Plants]. (2014). Astana: Art Print XXI [in Russian].

4 Bykov, B.A. (1966). Vvodnyi ocherk flory i rastitelnosti Kazakhstana [Introductory study on the flora and vegetation of Kazakhstan]. Rastitelnyi pokrov Kazakhstana - Vegetation cover of Kazakhstan. Alma-Ata: Nauka [in Russian].

5 Gudochkin, M.V., \& Chaban, P.S. (1958). Lesa Kazakhstana [Forests of Kazakhstan]. Alma-Ata: Kazgosizdat [in Russian].

6 Nikitin, S.A. (1975). Prichiny usykhaniia lesov v poime nizovia r. Ural [The reasons for the drying of forests in the floodplain of the down the Ural River]. Lesovedenie - Forest Science, 5, 66-69 [in Russian].

7 Vorobev, A.I. (1987). Topolevye lesa poimy r. Ural i ikh vozobnovlenie [Poplar forests of the Ural River floodplain and their renewal]. Lesnye ekosistemy v usloviiakh kontinentalnogo klimata - Forest ecosystems in conditions of continental climate. Krasnoyarsk: Krasnoyarsk University Press [in Russian].

8 Gorchakovskiy, P.L. (1968). Rasteniia evropeiskikh shirokolistvennykh lesov na vostochnom predele ikh areala [Plants of European broad-leaved forests at the eastern border of their areal]. Sverdlovsk [in Russian].

9 Pugachev, P.G. (1967). Geobotanicheskaia kharakteristika dubovykh i viazovykh lesov poimy srednego techeniia reki Urala [Geobotanical characteristics of oak and elm forests of the floodplain of the middle part of the Ural River]. Extended abstract of candidate's thesis. Sverdlovsk [in Russian].

10 Ageleuov, E.A. (1987). Flora poimy reki Ural [Flora of the floodplain of the Ural River]. Alma-Ata: Nauka [in Russian].

11 Gimadiyeva, F.Kh. (2002). Poimennye lesa Urala v predelakh stepnoi zony Priuralia [Floodplain forests of the Ural River within the steppe zone of the Transurals]. Extended abstract of candidate's thesis. Orenburg [in Russian].

12 Riabinina, Z.N., \& Gimadieva, F.Kh. (2014). Lesnaia rastitelnost v poime reki Ural [Forest vegetation in the floodplain of the Ural River]. Orenburg: Universitet [in Russian].

13 Darbaeva, T.E., Alzhanova, B.S., Bokhorova, S.N., \& Chukalina O.N. (2016). Istoricheskii analiz flory poimennykh lesov basseina reki Ural v predelakh Zapadno-Kazakhstanskoi oblasti [Historical analysis of the flora of floodplain forests of the Ural River basin within the West Kazakhstan region]. Vestnik Kazakhskogo natsionalnogo universiteta. Seriia Biologicheskaia - KazNU bulletin. Biology Series, 4, 69, 32-40 [in Russian].

14 Elekesheva, M.M. (2020). Rost, stroenie i produktivnost poimennykh nasazhdenii reki Ural Zapadno-Kazakhstanskoi oblasti [Growth, structure and productivity of floodplain plantations of the Ural River in the West Kazakhstan region]. Extended abstract of candidate's thesis. Moscow [in Russian].

15 Padalko, Y.A. \& Chibilyov, A.A. (2017). Problems of riverbed evolution in the basin of the Ural River. Doklady Earth Sciences, 475, 968-971. https://doi.org/10.1134/S1028334X17080268

16 Tulemisova, G., Abdinov, R., Kabdrakhimova, G., \& Janetov, T. (2017). Ecological state of the river Ural. Chemical Bulletin of Kazakh National University, 85 (2), 18-24. https://doi.org/10.15328/cb808

17 Padalko, Y.A. (2021). An assessment and prognosis of water resources use in regions of the transboundary basin of the Ural River in the medium term. IOP Conference Series: Earth and Environmental Science, 817, 012080. https://doi.org/10.1088/1755$1315 / 817 / 1 / 012080$

18 Čater, M. (2015). A 20-year overview of Quercus robur L. mortality and crown conditions in Slovenia. Forests, 6, 581-593. https://doi.org/10.3390/f6030581

19 Trudić, B., Avramidou, E., Fussi, B., Neophytou, C., Stojnić, S., \& Pilipović, A. (2021). Conservation of Quercus robur L. genetic resources in its south-eastern refugium using SSR marker system - a case study from Vojvodina province, Serbia. Austrian Journal of Forest Science, 138 (2), 117-140.

20 Selochnik, N.N. (2017). Mnogoletniaia dinamika starovozrastnykh nasazhdenii Tellermanovskikh dubrav [Long-term dynamics of old-grown stands of Tellerman oak forests]. Lesovedenie - Forest Science, 2, 59-68 [in Russian]. 
21 Skiadaresis, G., Schwarz, J.A., \& Bauhus, J. (2019). Groundwater extraction in floodplain forests reduces radial growth and increases summer drought sensitivity of pedunculate oak trees (Quercus robur L.). Frontiers in Forests and Global Change, 2, Article 5. https://doi.org/10.3389/ffgc.2019.00005

22 Bernoux, M., Branca, G., Carro, A., Lipper, L., Smith, G., \& Bockel, L. (2010). Ex-ante greenhouse gas balance of agriculture and forestry development programs. Scientia Agricola, 67 (1), 31-40. https://doi.org/10.1590/s0103-90162010000100005

23 Bernoux, M., Schiettecatte, L.-S., Tinlot, M., Bockel, L., Branca, G., Gentien, A., \& Colomb, V. (2014). Ex-Ante Carbon balance Tool (EX-ACT) - Technical Guidelines. Easy Pol module, 218. Rome: FAO.

24 Bockel, L., Debrune, O., Toudert, A., Doro, E., Lozada, O., \& Schiettecatte, L.-S. (2017). Ex-Ante Carbon-balance Tool for Value Chain (EX-ACT VC) (Guidelines). Rome: FAO.

25 Seddon, N., Sengupta, S., García-Espinosa, M., Hauler, I., Herr, D., \& Rizvi, A.R. (2019). Nature-based Solutions in Nationally Determined Contributions: Synthesis and recommendations for enhancing climate ambition and action by 2020. Gland, Switzerland and Oxford, UK: IUCN and University of Oxford.

26 Strategicheskii plan Ministerstva ekologii, geologii i prirodnykh resursov Respubliki Kazakhstan na 2020-2024 gody. Utverzhden prikazom Ministra ekologii, geologii i prirodnykh resursov Respubliki Kazakhstan ot 14 yanvaria 2020 goda № 11-P [Strategic Plan of the Ministry of Ecology, Geology and Natural Resources of the Republic of Kazakhstan for 2020-2024. Approved by the Order of the Minister of Ecology, Geology and Natural Resources of the Republic of Kazakhstan No. 11-P dated January 14, 2020]. (2020) [in Russian].

27 Svodnyi proekt organizatsii i razvitiia lesnogo khoziaistva Zapadno-Kazakhstanskogo lesokhoziaistvennogo proizvodstvennogo obedineniia Zapadno-Kazakhstanskoi oblasti [Summary project of the organization and development of forestry of the West Kazakhstan Forestry Production Association of the West Kazakhstan region]. (1993). Almaty [in Russian].

28 Svodnyi lesoustroitelnyi proekt po Zapadno-Kazakhstanskoi oblasti. (Poiasnitelnaia zapiska) [Summary project of forest management for the West Kazakhstan region (Explanatory note)]. (2018). Almaty: Kazakh Forest Management Enterprise [in Russian].

29 Chashina, B., Ramazanova, N., Atasoy, E., Berdenov, Z., \& Ilieș, D.C. (2020). Natural recreation potential of the West Kazakhstan region of the Republic of Kazakhstan. Geo Journal of Tourism and Geosites, 32 (4), $1355-1361$. https://doi.org/10.30892/gtg.32424-580

30 Gebrehiwot, K. \& Hundera, K. (2014). Species composition, plant Community structure and natural regeneration status of Belete Moist Evergreen Montane Forest, Oromia Regional state, Southwestern Ethiopia. Momona Ethiopian Journal of Science, 6, 1, 97-101. https://doi.org/10.4314/mejs.v6i1.102417

31 Mchenga, I.S., \& Ali, A.I. (2014). Natural regeneration of mangroves in a degraded and non-degraded tropical forest of Zanzibar Island. Journal of Global Biosciences, 3, 1, 334-344.

32 Poniatovskaia, V.M. (1964). Uchet obiliia i osobennosti razmeshcheniia vidov v estestvennykh rastitelnykh soobshchestvakh [Accounting the abundance and features of the placement of species in natural plant communities]. Polevaia geobotanika - Field geobotany. (Vol. 3). Moscow; Leningrad: Nauka [in Russian].

33 Flora Kazakhstana [Flora of Kazakhstan] (1956-1966). (Vols. 1-9). Alma-Ata: Nauka [in Russian].

34 IPNI. (2021). International Plant Names Index. Published on the Internet http://www.ipni.org. The Royal Botanic Gardens, Kew, Harvard University Herbaria \& Libraries and Australian National Botanic Gardens.

35 Bockel, L., Grewer, U., Fernandez, C., \& Bernoux, M. (2013). EX-ACT user manual: estimating and targeting greenhouse gas mitigation in agriculture. Rome: FAO.

36 Grewer, U., Bockel, L., \& Bernoux, M. (2013). EX-ACT quick guidance manual: estimating and targeting greenhouse gas mitigation in agriculture. Rome: FAO.

37 Kehayova, E., Mislimshoeva, B., Abdurasulova, G., \& Wippel, B. (2020). Report on options for nature-based solutions to enhance NDC commitments in three countries (Kazakhstan, Kyrgyzstan and Tajikistan). Technical and financial analysis of promising nature-based solutions for climate change. Dushanbe: Deutsche Gesellschaft für Internationale Zusammenarbeit (GIZ) GmbH.

38 Besschetnov, P.P., \& Maltsev, S.N. (1981). Redkie i tsennye rasteniia Kazakhstana. Derevia i kustarniki [Rare and valuable plants of Kazakhstan. Trees and shrubs]. Alma-Ata: Kainar [in Russian].

39 Bykov, B.A., \& Arystangaliev, S.A. (1987). Okhrana botanicheskikh obektov v Kazakhstane [Protection of botanical objects in Kazakhstan]. Okhrana redkikh vidov rastenii i rastitelnosti Kazakhstana - Protection of rare species of plants and vegetation in Kazakhstan. Alma-Ata: Nauka [in Russian]. 